\title{
PENYELESAIAN SENGKETA PENGALIHAN SAHAM \\ PERUSAHAAN PEMBANGKIT LISTRIK ENERGI PANAS BUMI \\ MELALUI PUTUSAN ARBITRASE ASING (SIAC)
}

\author{
Oleh: \\ I Gusti Agung Ayu Gita Pritayanti Dinar ${ }^{1}$
}

\begin{abstract}
Arbitration is one of popular means to solve disputes arise between parties in international business nowadays. Arbitration characteristics such as: confidentiality; "party autonomy" (principle which gives both parties freedom to agree on arbitration institution or ad hoc arbitration, to appoint an arbitrator, arbitration procedure, place of arbitration, governing law) and also international enforceability due to the New York Convention 1958 are regarded as part of the main advantages of arbitration.

This research is a normative law using concept analysis approach legal, regulatory approaches undertaken by examining legislation relevant to the issues of law and experiences to approach a case of transfer of shares Bali Power Corporate. Sources of legal materials used in this study are such as related literature, journals, articles and thesis that are relevant to the subject matter.

The results of this study indicate that partial award (SIAC) has a binding force for the parties to the dispute. Legal implications arising from this decision that the party whose breach the contract has an obligation to replace the damage of PT. Bali Tenaga Corporate since the contract was signed.
\end{abstract}

Keywords: Shares, Dispute Resolutions, International Arbitration.

\section{Pendahuluan}

\section{I.1. Latar Belakang}

Seiring dengan pertumbuhan ekonomi Indonesia dewasa ini, maka pemerintah berupaya untuk mengembangkan ekonomi dari berbagai sektor salah satunya bidang eksplorasi pembangkit listrik tenaga panas bumi.

Mahasiswa Magister Ilmu Hukum Universitas Udayana, Denpasar,Bali. Alamat J1. Kresna, Bona Kelod, Gianyar, e-mail : gitadinar@gmail.com
Bali Power Corporate (identitas perusahaanbukan sebenarnyadan selanjutnya disebut BPC) adalah sebuah perusahaan asing yang didirikan di Bermuda pada tanggal 25 November 1994 yang bergerak dalam bidang eksplorasi tenaga panas bumi (geothermal) yang didirikan berdasarkan hukum Bermuda dan berkedudukan di Hamilton HMDX, Bermuda. Bali Power Corporate(BPC) memiliki kontrak kerjasama proyek eksplorasi pembangkit listrik tenaga panas bumi di Bali dengan PERTAMINA dan PLN yang dibuat pada tahun 1995. 
Pada tahun 2001 PT. Tenaga Bumi Co (identitas perusahaan bukan sebenarnya dan selanjutnya disebut PT. TBC) telah membeli 100\% (seratus persen) saham Bali Power Corporate. PT TBC adalah sebuah perseroan terbatas yang bergerak dalam bidang geothermal dan kontraktor yang berkedudukan di Denpasar, Bali.

Dalam rangka mengembangkan proyek eksplorasi ini, para pemegang saham PT. TBC sepakat untuk menerima investor asing asal Jepang yang juga dikenal dengan Mosi Mosi Co. Ltd (identitas perusahaan bukan sebenarnya dan selanjutnya disebut MMC) yang akan membeli saham mayoritas yaitu $70 \%$ (tujuh puluh persen) saham Bali Power Corporate. Kesepakatan masing-masing pihak kemudian dituangkan dalam transaksi jual beli saham dengan penandatanganan Share Purchase Agreement between PT. Tenaga Bumi Co and Mosi Mosi Co. Corporate (selanjutnya akan disebut SPA) pada tanggal 7 September 2004. Transaksi jual beli saham ini tidak berjalan dengan mulus sehingga terjadi perselisihan antara para pihak dikarenakan pengalihan saham yang telah dilakukan dan diregestrasikan di Bermuda tidak disertai dengan pembayaran untuk transaksi dari 70\% (tujuh puluh persen) saham sesuai dengan kesepakatan yang dituangkan dalam SPA tersebut.

Pihak PT. TBC mengklaim MMC melalui Singapore International Arbitration Centre (SIAC) pada bulan Juli 2010 dan telah diputus dengan Partial Award SIAC tahun 2013 yang dalam salah satu putusannya menyatakan bahwa pihak MMC telah melanggar kontrak (SPA) atau breach the contract terhadap kewajibannya untuk melakukan pembayaran sesuai dengan tahap-tahap yang telah disepakati bersama sebelumnya dalam SPA. Tidak hanya itu, MMC juga harus mengganti sejumlah kerugian yang ditimbulkan karena terhambatnya operasional pembangkit listrik ini sejak tahun 2004 hingga sekarang.

\section{I.2. Rumusan Masalah}

1. Apakah Partial Award SIAC mempunyai kekuatan hukum mengikat untuk sengketa pengalihan saham Bali Power Corporate?

2. Apakah implikasi hukum Partial Award SIAC terhadap transaksi saham Bali Power Corporate antara PT. Tenaga Bumi Corporate dan Mosi Mosi Corporate?

\section{I.3. Tujuan Penelitian}

Adapun yang menjadi tujuan dari penelitian ini adalah sebagai berikut:

\section{I.3.1. Tujuan Umum}

Penelitian ini secara umum bertujuan untuk mengembangkan Ilmu Hukum terkait dengan paradigma science as a process (ilmu sebagai proses), dengan paradigma ini ilmu tidak akan pernah mandeg (final) dalam penggaliannya atas kebenaran ${ }^{2}$. Dalam penelitian ini adalah penggalian atas kebenaran dari Penyelesaian Sengketa Pengalihan Saham Bali Power Corporate

\footnotetext{
Program Studi Magister (S2)Ilmu Hukum Program Pasca SarjanaUniversitas Udayana, 2013, Pedoman Penulisan Usulan Penelitian Tesis dan Penulisan Tesis Program Studi Magister (S2) Ilmu Hukum, Denpasar, hal. 43.
} 
Melalui Putusan Arbitrase Asing Singapore International Arbitration Centre (SIAC).

\section{I.3.2. Tujuan Khusus}

Sedangkan yang menjadi tujuan khusus dari penelitian ini adalah sebagai berikut:

1. Untuk mengetahui apakah Partial Award SIAC mempunyai kekuatan hukum mengikat untuk sengketa pengalihan saham Bali Power Corporate.

2. Untuk mengetahui apakah implikasi hukum bagi Bali Power Corporate atas putusan Partial Award SIAC tersebut.

\section{I.4. Metode Penelitian}

Karya ilmiah ini menggunakan Metode Penelitian Hukum Normatif yaitu menguji kebenaran ada tidaknya sesuatu fakta disebabkan oleh suatu faktor tertentu. ${ }^{3}$ Penelitian hukum yang dilakukan dengan cara meneliti bahan pustaka atau data sekunder belaka, dapat dinamakan penelitian hukum normatif atau penelitian kepustakaan. ${ }^{4}$

Adapun pendekatan yang digunakan dalam karya ilmiah ini adalah sebagai berikut:

1. Pendekatan Analisa Konsep Hukum (Analitical and Conceptual Approach) yaitu segala permasalahan ditelaah berdasarkan konsep, teori, asas-asas, dan peraturan perundang-undangan yang berlaku. Konsep itu universal.

Peter Mahmud Marzuki,2011, Penelitian Hukum, Kencana, Jakarta, hal. 35.

4 Soerdjono Sukanto dan Sri Mamuji, 2013, Penelitian Hukum NormatifSuatu Ttinjauan Singkat, Rajagrafindo Perkasa, Jakarta, hal. 13.
Oleh karena itulah penulis perlu menelaah pandangan-pandangan sarjana hukum dari berbagai negara mengenai hal tersebut. Disinilah kemampuan peneliti hukum untuk memahami substansi ilmu hukum yang benar-benar diperlukan. ${ }^{5}$

2. Pendekatan Perundang-undangan (The Statue Approach)yaitudenganmeneliti, membandingkan dan menganalisa peraturan perundang-undangan dan regulasi yang mengatur tentang penyelesaian sengketa pengalihan saham Bali Power Corporate melalui Konvensi New York Tahun 1958; PeraturanMahkamahAgung (PERMA) Nomor 1 tahun 1990 tentang Tata Cara Pelaksanaan Putusan Arbitrase Asing; Undang-Undang Republik Indonesia No. 30 Tahun 1999 tentang Arbitrase dan Alternatif Penyelesaian Sengketa dan Peraturan Mahkamah Agung (PERMA) Nomor 1 tahun 1990 tentang Tata Cara Pelaksanaan Putusan Arbitrase Asing.

3. Pendekatan Kasus (Case Approach) yaitu dengan menganalisa sengketa pengalihan saham Bali Power Corporate yang diselesaikan melalui SIAC.

Dalam menggunakan pendekatan kasus, yang perlu dipahami oleh peneliti adalah ratio decidendi, yaitu alasan - alasan hukum yang digunakan oleh hakim untuk sampai kepada putusannya. ${ }^{6}$

Peter Mahmud Marzuki, Op.Cit, hal. 137.

Peter Mahmud Marzuki, Op.Cit. hal 119. 


\section{HASIL DAN PEMBAHASAN}

\subsection{Kekuatan Mengikat Putusan}

Arbitrase Asing Terhadap Sengketa

Pengalihan Saham Bali Power

\section{Corporate.}

Suatu putusan arbitrase dapat dikatakan mengikat para pihak yang bersengketa jika dalam klausul perjanjian yang mengikat kedua belah pihak terdapat ketentuan yang mengatur pilihan hukum untuk sengketa yaitu arbitrase. Sehingga putusan arbitrase sudah merupakan suatu keharusan bagi kedua belah pihak untuk mengakui dan mentaatinya dikarenakan sifat putusan arbitrase yang final dan mengikat.

Dalam putusan parsial arbitrase, menurut hemat penulis sudah jelas menyatakan bahwa pihak MMC telah melanggar isi kontrak atau breach the contract/agreement dan counterclaim/ tanggapan dari MMC sepenuhnya ditolak oleh majelis arbiter. Putusan parsial ini sudah mengikat kedua belah pihak sejak putusan ini dikeluarkan oleh majelis arbiter hanya saja besarnya kerugian dari pihak TBC akan ditetapkan pada final award.

The general principle is that the party in breach (the defendant) can only be liable for losses which were within the reasonable contemplation of the parties at the time the contracty was made. ${ }^{7}$ Pada intinya bahwsa pihak MMC sebagai pihak yang melanggar kontrak mempunyai kewajiban untuk memberikan ganti rugi secara wajar

Hellen Bond and Peter Kay, 1995, Business Law, Blackstones Press, Great Britain, hal. 216. dari kesepakatan kontrak yang telah dibuat sebelumnya.

Suatu putusan, baik putusan arbitrase maupunpengadilanhanya dapatdilaksanakan (eksekusi) setelah putusan tersebut bersifat final. Namun karena beberapa hal atau keadaan tertentu atau memaksa adakalanya suatu putusan dapat segera dilaksanakan segera setelah putusan tersebut dijatuhkan, seperti putusan proposionil. ${ }^{8}$

Jika arbitrase memiliki beberapa keunggulan dibandingkan dengan peradilan maka arbitrase pun memiliki kelemahan. Pelaksanaan keputusan arbitrase membutuhkan jaminan bonafiditas, dalam bentuk kerelaan para pihak untuk mentaati keputusan tersebut. Suatu keputusan arbitrase dapat sama sekali kehilangan kekuatannya jika salah satu pihak atau pihak-pihak yang terlibat dalam sengketa tidak memenuhi syarat bonafiditas. ${ }^{9}$

Terdapat beberapa asas yang dikenal dalam pemberlakuan putusan arbitrase asing, diantaranya yaitu: ${ }^{10}$

1. Asas Executorial Kracht, yaitu putusan arbitrase memiliki kekuatan eksekusi sebagaimana ditegaskan dalam Pasal 2 Perma No. 1 Tahun 1990, menurut pasal ini putusan arbitrase asing disamakan

Suleman Batubara \& Orinton Purba, 2013, Arbitrase Internasional Penyelesaian Sengketa Investasi Asing Melalui ICSID, UNCITRAL dan SIAC, Raih Asa Sukses, Jakarta, hal. 163.

9 Ida Bagus Wyasa Putra, 2008, Aspek-Aspek Hukum Perdata Internasional Dalam Transaksi Bisnis Internasional, Refika Aditama, Bandung, Cetakan Kedua, hal. 79.

10 Frans Hendra Winarta, 2012, Hukum Penyelesaian Sengketa Arbitrase Nasional Indonesia dan Internasional, Pena Grafika, Jakarta, hal. 77. 
dengan putusan pengadilan yang telah mempunyai kekuatan hukum tetap.

2. Asas Resiprositas yaitu asas dasar yang diatur dalam Konvensi New York 1958 bahwa setiap negara yang ikut menandatangani Konvensi New York 1958 berhak menyatakan dalam ratifikasi untuk pengakuan dan pengeksekusian puitusan arbitrase asingdidasarkan atas asas ini.

3. Asas Pembatasan yaitu suatu asas yang diatur dalam Perma No. 1 Tahun 1990 mengenai pembatasan putusan arbitrase asing hanya pada sengketa dalam ruang lingkup dagang.

4. Asas Ketertiban Umum yang diatur dalam Perma No. 1 Tahun 1990 mengenai pemberlakuan suatu putusan arbitrase asing yang hanya jika tidak bertentangan dengan ketertiban umum.

Arbitrasesebagailembagapenyelesaian sengketa yang berdiri sendiri telah dikenal cukup lama oleh para pakar hukum di dunia. Salah satunya adalah Emmanuel Gaillard sebagai guru besar ilmu hukum terkemuka di bidang arbitrase di Perancis.

Gaillard memperkenalkan filsafat transnasional untuk arbitrase, khususnya legalitas atau kekuatan hukum arbitrase. ${ }^{11}$

Teori ini melihat negara-negara secara keseluruhan, tidak sendiri-sendiri atau secara individual. Menurut teori ini, negara-negara umumnya mengakui keabsahan arbitrase dan

11 Huala Adolf , 2014, Dasar-Dasar, Prinsip \& Filosofi Arbitrase, Keni Media, Bandung, hal. 44. bersedia untuk mengakui putusan arbitrase karena terpenuhinya syarat sah perjanjian arbitrase sebagai dasar untuk menentukan keabsahan putusan arbitrase. ${ }^{12}$

Penganut teori ini berpandangan bahwa di dalam dunia yang heterogen, baik kebangsaan para pihak, tempat arbitrase, kebangsaan arbitrator atau hukum yang berlaku, adalah berbeda-beda. Karena itu ada alasan yang kuat untuk memberi setiap negara, termasuk negara yang menjadi tempat arbitrase berlangsung, kewenangan sendiri untuk mengatur proses arbitrasenya. ${ }^{13}$

Teori ini mengakui kebebasan arbitrase untuk menerapkan pelaksanaan aturan-aturan hukum acara yang bersifat transnasional atau lintas negara. Sehingga masing-masing pihak yang bersengketa sudah sepatutnya untuk mengakui dan melaksanakan hasil putusan arbitrase internasional, mengingat putusan ini tidak hanya berlaku ditempat dimana proses arbitrase ini dilaksanakan namun juga mengikat masing-masing pihak yang berbeda negara tersebut.

Jakubowski, sarjana Polandia, memegang jabatan yang sangat penting di bidang arbitrase. Beliau pernah menjabat sebagai ketua badan arbitrase Polandia, menjabat anggota pada lembaga arbitrase internasional terkemuka di dunia, yaitu the Permanent Court of Arbitration dan the International Council for Commercial Arbitration. ${ }^{14}$

Ibid, hal. 47.

Ibid, hal. 48.

Ibid, hal. 43. 
Jerzy Jakubowskimemandangarbitrase sebagai suatu lembaga penyelesaian sengketa yang digunakan oleh bangsa-bangsa dan di berbagai kultur di dunia. Karena itulah lembaga arbitrase dipandang sebagai suatu lembaga buatan dan ciptaan manusia yang sifatnya universal. ${ }^{15}$

Arbitrase juga merupakan suatu produk manusia untuk memenuhi kebutuhan dan keinginan manusia untuk menyelesaikan sengketa para pihak oleh pihak ketiga yang sifatnya netral dan memiliki kepercayaan serta otoritas dari para pihak. ${ }^{16}$

Dalam pemaparannya Jakubowski juga mengatakan aturan arbitrase yang ada diseluruh negara tidaklah seragam, namun aturan arbitrase menunjukkan adanya keharmonisan dan kepastian hukum.

Dari uraian tersebut di atas dapat diketahui bahwa prinsip otonomi para pihak dalam penerapan kontrak atau perjanjian khususnya untuk melakukan pilihan hukum telah diakui secara universal. Walaupun terdapat perbedaan cara pendekatan yang dilakukan dalam metode pilihan hukumnya, tetapi pada prinsipnya hukum yang berlaku bagi para pihak dalam suatu kontrak adalah hukum yang telah mereka pilih. Jika para pihak telah menentukan klausul bahwa hukum yang berlaku untuk kontrak ini adalah melalui SIAC, maka bagi para pihak pilihan hukum ini haruslah ditaati dan dilaksanakan.

Darikeduateoritersebutdiatas, menurut hemat penulis bahwa suatu putusan arbitrase

Ibid, hal. 50

Ibid, hal. 50 . adalah mengikat masing-masing pihak yang bersengketa dan dapat diberlakukan di negara dimana obyek sengketa ini berkedudukan dan memiliki kepastian hukum dikarenakan sifatnya yang final dan mengikat. Putusan parsial arbitrase dari sengketa BPC ini adalah mengikat kedua belah pihak dikarenakan dalam kesepakatan jual beli saham kedua belah pihak telah dicantumkan secara jelas pilihan hukumnya jika terjadi perselisihan. Telah disebutkan juga dalam putusan parsial tersebut bahwa pihak pembeli atau MMC dinyatakan telah wanprestasi dan melanggar isi perjanjian yang telah disepakati bersama, namun demikian putusan parsial tetap dapat dijadikan acuan landasan hukum dan pedoman bagi PT. TBC untuk mengambil langkah hukum dalam pengambil alihan asset BPC di Bali yang selama ini telah dikuasai oleh MMC serta sebagai landasan untuk menghitung jumlah kerugian yang dialami selama proyek tidak berjalan.

Suatu putusan yang telah sesuai dengan persyaratan formildanmateriiladalah putusan yang berlandaskan hukum dan mengikat para pihak. Putusan parsial arbitrase ini telah memenuhi persyaratan yang diatur dalam UNCITRAL sehingga mempunyai kekuatan hukum yang mengikat.

\subsection{Implikasi Hukum Putusan Parsial Arbitrase Asing Terhadap Sengketa Pengalihan Saham Bali Power Corporate.}

Selain final dan mengikat, putusan SIAC bersifat rahasia sehingga tidak dapat dipublikasikan sesuai dengan pasal 35 ayat 1, SIAC Rules 2010 yang berbunyi: "The 
parties and the Tribunal shall at all the times treat all matters relating to the proceedings and the award as confidential."

Asas pemeriksaan pintu tertutup, berlanjut terus pada pengucapan putusan. Mahkamah arbitrase dilarang untuk mempublikasikan putusan. Penegasan larangan ini misalnya diatur dalam pasal 48 ayat 5 ICSID yang menyatakan: "The Centre shall not publish the award without the consent of the parties". Begitu pula diatur dalam pasal 32 ayat 2 UNCITRAL, terdapat larangan yang sama: "The award may be made public only eith the consent of both parties". ${ }^{17}$

Jadi hanya para pihak yang bersengketa saja yang boleh mendapatkan asli dan salinan putusan SIAC tersebut serta masing-masing pihak tidak boleh mempublikasikannya kepada siapapun. Hal ini tentu saja terkait dengan kerahasiaan, kepentingan dan nama baik atau reputasi masing-masing pihak yang bersengketa.

Setiap permasalahan yang dibawa ke pengadilan mempunyai harapan agar pengadilan dapat menjalankan fungsinya untuk mendapatkan hal-hal sebagai berikut: ${ }^{18}$

1. Equality before the law, yakni untuk diperlakukan sama tanpa memandang warna kulit, kedudukan dan status dari masyarakat.

Yahya Harahap, 1991, Arbitrase, Pustaka Kartini, Jakarta, hal. 328-330.

18 Munir Fuady, 2008, Pengantar Hukum Bisnis Menata Bisnis Modern di Era Global, Citra Aditya Bakti, Bandung, hal. 263.
2. Opportunity to be heard, yakni untuk mendapatkan kesempatan untuk didengar keluhan dan pembelaannya.

3. Law enforcement, yang merupakan hak setiap warga negara untuk meminta otoritas untuk menjalankan hukum dan putusan pengadilan.

Berikut adalah analisa penulis mengenai implikasi hukum dari kutipan putusan parsial arbitrase dari penelitian ini adalah sebagai berikut:

1. MMC dinyatakan telah melanggar kontrak Share Purchase Agreement tanggal 7 September 2004 antara PT. TBC dengan MMC sehingga MMC harus segera menyelesaikan tanggung jawabnya sesuai dengan kontrak tersebut untuk membayar sejumlah saham yang telah ditransfer dari PT. TBC menjadi atas nama MMC.

2. MMC diharuskan untuk membayar seluruh biaya kerugian yang diitimbulkan sesuai dengan final award yang sedang diproses di SIAC;

Hasil putusan parsial initelah disepakati kedua belah pihak yang bersengketa. Melalui pembuktian dari persidangan arbitrase di SIAC telah mengungkapkan seluruh pembuktian yang ada. Pihak MMC juga dinyatakan belum memenuhi kewajibannya untuk membayar sejumlah saham yang telah ditransfer melalui corporate secretary di Bermuda. Penyelesaian sengketa melalui SIAC ini menurut hemat penulis telah memberikan suatu putusan yang adil dan sesuai untuk kedua belah pihak dimana masing-masing pihak sudah mendapatkan 
hak dan kewajibannya walaupun dengan melalui proses yang cukup panjang dengan biaya yang tidak sedikit.

Dengan demikian maka hukum memiliki fungsi dan peranan yang sangat penting dalam masyarakat terutama dalam hal ini adalah kalangan pengusaha, dan memiliki fungsi kebaikan dalam masyarakat demi mencapai keadilan, kepastian hukum, ketertiban, dan kemanfaatan.

\section{PENUTUP}

\section{Simpulan}

(1) Partial Award SIAC ini mempunyai kekuatan hukum mengikat dalam sengketa pengalihan saham Bali Power Corporate, dikarenakan dengan berlandaskan putusan ini pihak PT. Tenaga Bumi Baru dapat mengajukan keberatan dan balik nama atas 70\% saham di Codan, sekretariat Bali Power Corporate di Bermuda, tanpa putusan ini maka pihak PT. Tenaga Bumi Corporate tidak memiliki dasar hukum untuk mengambil alih kembali pengalihan $70 \%$ saham tersebut. Putusan parsial ini sudah mengikat kedua belah pihak sejak putusan ini dikeluarkan oleh majelis arbiter hanya saja besarnya kerugian dari pihak Claimant akan ditetapkan pada saat putusan final atau final award mengingat diperlukannya tenaga ahli baik data keuangan serta ahli geologi untuk menghitung besarnya kerugian yang timbul dikarenakan proyek yang tidak berjalan selama kurang lebih 10 tahun sejak penandatanganan Share Purchase Agreement antara PT. Tenaga Bumi Corporate dan Mosi Mosi Corporate.

(2) Implikasi hukum Partial Award SIAC terhadap transaksi saham Bali Power Corporate adalah sebagai berikut:

a. Putusan ini menyatakan bahwa Mosi Mosi Corporate yang dinyatakan telahmelanggarkontrak Share Purchase Agreement tanggal 7 September 2004 antara PT. Tenaga Bumi Corporate dengan Mosi Mosi Corporate sehingga Mosi Mosi Corporate harus segera menyelesaikan tanggung jawabnya sesuai dengan SPA tersebut untuk membayar sejumlah saham yaitu $70 \%$ saham yang telah ditransfer dari PT. Tenaga Bumi Corporate menjadi atas nama Mosi Mosi Corporate.

b. Mosi Mosi Corporate diharuskan untuk membayar seluruh biaya kerugian yang diitimbulkan dari sengketa ini.

\section{Saran-saran.}

(1) Mengingat transaksi pengalihan saham dengan para pihak yang berbeda kewarganegaraan atau lintas negara memiliki resiko yang cukup tinggi untuk terjadinya wanprestasi maka sebaiknya para pelaku usaha lebih menerapkan prinsip kehatihatian, lebih selektif dan ada baiknya jika terlebih dahulu melakukan uji tuntas (legal due diligence) yang lebih 
komprehensif terhadap calon mitra dalam setiap bentuk kerjasama apapun dan tetap memperhitungkan resiko terburuk jika terjadi suatu perselisihan maka akan dibutuhkan biaya litigasi yang lebih tinggi jika pilihan domisili hukumnya berada diluar Indonesia.

(2) Sebaiknya dalam klausul Share Purchase Agreement dicantumkan dalam salah satu klausul dari payment of shares bahwa seluruh pembayaran dapat disimpan dalam escrow account melalui escrow agent sehingga kewajiban pihak Mosi Mosi Corporate untuk membayar saham secara bertahap sesuai kesepakatan sebelumnya tersebut lebih terkontrol dan dapat diawasi oleh pihak escrow agent tersebut.

\section{DAFTAR PUSTAKA}

Frans Hendra Winarta, 2012, Hukum Penyelesaian Sengketa Arbitrase Nasional Indonesia dan Internasional, Pena Grafika, Jakarta.

Huala Adolf, 2014, Dasar-Dasar, Prinsip \& Filosofi Arbitrase, Keni Media, Bandung.

Hellen Bond and Peter Kay, 1995, Business Law, Blackstones Press, Great Britain. Ida Bagus Wyasa Putra, 2008, Aspek-Aspek Hukum Perdata Internasional Dalam Transaksi Bisnis Internasional, Refika Aditama, Bandung.

Munir Fuady, 2008, Pengantar Hukum Bisnis Menata Bisnis Modern di Era Global, Citra Aditya Bakti, Bandung.
Program Studi Magister (S2)Ilmu Hukum Program Pasca SarjanaUniversitas Udayana, 2013, Pedoman Penulisan Usulan Penelitian Tesis dan Penulisan Tesis Program Studi Magister (S2) Ilmu Hukum, Denpasar.

Peter Mahmud Marzuki,2011, Penelitian Hukum, Kencana, Jakarta.

Soerdjono Sukanto dan Sri Mamuji, 2013, Penelitian Hukum Normatif Suatu Ttinjauan Singkat, Rajagrafindo Perkasa, Jakarta.

Suleman Batubara \& Orinton Purba, 2013, Arbitrase Internasional Penyelesaian Sengketa Investasi Asing Melalui ICSID, UNCITRAL dan SIAC, Raih Asa Sukses, Jakarta.

Yahya Harahap, 1991, Arbitrase, Pustaka Kartini, Jakarta. 